Moulita, et al Media Literacy for Herbalist in Medan City

\title{
Media Literacy for Herbalist in Medan City
}

\author{
Moulita $^{1 *}$, Mazdalifah ${ }^{1}$, Yovita Sabarina Sitepu ${ }^{1}$ \\ ${ }^{1}$ Department of Communication Study, Faculty of Social and Political Sciences, Universitas \\ Sumatera Utara \\ *Email: moulita@usu.ac.id
}

\begin{abstract}
The rise of hoax news circulating on social media at a certain point can cause confusion and anxiety in society. Therefore, this community service group took the initiative to carry out a media literacy activity for the herbs seller (herbalist) group of Yayasan Perempuan Perkotaan Medan (YP2M). This activity aims to facilitate the group so that they have the skills to respond to the hoax news. The materials provided include what the news is, the news values, the characteristics of hoax news, and the examples of hoax news that are widely spread in society through the social media. This program was held in Gedung Johor, Medan on August 2020 which was attended by around 20 participants.
\end{abstract}

Keywords: media literacy, hoax news, YP2M

\begin{abstract}
Abstrak
Maraknya berita hoaks yang beredar di media sosial pada titik tertentu dapat menimbulkan kebingungan dan kecemasan di masyarakat. Oleh karenanya, kelompok pengabdian ini berinisiatif melaksanakan satu kegiatan penyuluhan kepada kelompok penjual jamu Yayasan Perempuan Perkotaan Medan (YP2M) agar memiliki kecakapan dalam menyikapi berita hoaks tersebut. Materi yang diberikan antara lain apa itu berita, nilai-nilai berita, ciri-ciri berita hoaks serta contoh berita hoaks yang banyak beredar di kalangan masyarakat melalui media sosial. Kegiatan dilaksanakan di Gedung Johor, Medan pada Agustus 2020 yang diikuti sekitar 20 orang peserta.
\end{abstract}

Kata kunci: literasi media, berita hoaks, YP2M

\section{PENDAHULUAN}

Kecakapan literasi media diperlukan oleh semua orang sebagai perlengkapan agar mereka dapat menggunakan media dengan aman dan bermanfaat. Gagasan literasi media itu sendiri merupakan respon atas pertumbuhan media massa yang sangat cepat, terlebih lagi media baru atau kita kenal dengan media sosial saat ini. Semakin banyak elemen masyarakat yang dilibatkan dalam kegiatan ini, diharapkan akan semakin tinggi kesadaran dalam menggunakan media dengan cerdas dan bijak. Iriantara (2009) menyatakan bahwa pemberdayaan masyarakat atau khalayak merupakan salah satu prinsip dalam pendidikan literasi media.

Potter menyebutkan bahwa terdapat 4 aspek utama yang sering dikaitkan dengan literasi media, di antaranya: 1) media massa memiliki potensi dampak atau efek negatif bagi seseorang, 2) tujuan 
literasi media adalah membantu orang untuk melindungi dirinya dari efek negatif tersebut, 3) literasi media perlu ditanamkan pada diri seseorang karena tidak didapatkan secara alamiah sejak lahir, dan 4) literasi media bersifat multidimensional baik kognitif, afektif, maupun perilaku pada diri individu, serta berkaitan secara institusional dan budaya (dalam Herlina, 2019).

YP2M adalah salah satu kelompok yang bergerak di bidang pemberdayaan perempuan Kota Medan, yang didirikan pada tahun 2000 oleh seorang akademisi FISIP Universitas Sumatera Utara, Mazdalifah. Kegiatan utama Yayasan ini adalah memberikan dana bergulir berupa bantuan modal usaha, yang akan dikembalikan dalam kurun waktu satu tahun oleh para perempuan anggota YP2M, proses pengguliran dana hanya dari cicilan satu kelompok ke kelompok yang lain (Redaksi, 2016). Dengan merekrut para penjual jamu sebagai anggotanya, kelompok ini aktif mengembangkan diri agar tidak hanya berdaya secara finansial, namun juga memiliki wawasan dan pengetahuan terhadap isu-isu yang sedang berkembang.

Oleh karenanya, untuk menambah pengetahuan dan keterampilan para penjual jamu ini, tim pengabdian menyelenggarakan kegiatan berupa penyuluhan yang memberikan materi tentang berita dan berita hoaks. Tujuannya adalah agar peserta dapat membekali dirinya dari paparan berita-berita yang tidak jelas kebenarannya. Dengan demikian, mereka juga dapat menjadi garda bagi keluarganya dalam menyikapi berbagai pemberitaan yang diterima melalui media sosial.

\subsection{Permasalahan Mitra}

Secara khusus, permasalahan yang dialami mitra pengabdian pada masyarakat ini adalah kurangnya pengetahuan dan keterampilan anggota YP2M dalam menganalisis berita hoaks yang sering beredar di media sosial.

\subsection{Tujuan Kegiatan Pengabdian}

Tujuan pengabdian masyarakat ini adalah memberi penyuluhan kepada anggota YP2M agar mendapatkan pengetahuan mengenai berita dan nilai-nilai di dalamnya, serta memiliki informasi yang baik tentang apa itu berita hoaks dan contoh-contohnya.

\section{METODE PELAKSANAAN}

Tim pengabdian melakukan beberapa tahapan untuk mewujudkan pelaksanaan kegiatan ini:

1. melakukan pertemuan dengan pengurus dan beberapa orang anggota YP2M untuk menyatakan maksud dan tujuan melaksanakan kegiatan penyuluhan. Anggota merespon positif rencana kegiatan ini, karena mereka juga sering mengadakan kegiatan-kegiatan sejenis untuk menambah ilmu dan pengetahuan para anggotanya.

2. tim melakukan beberapa persiapan seperti menyiapkan materi pelatihan tentang berita hoaks, lokasi, peralatan pendukung, konsumsi untuk peserta, dan sebagainya.

3. pelaksanaan kegiatan yang diikuti sekitar 20 orang anggota YP2M yang berasal dari Kelompok Karya Tani, Karya Wisata, dan Helvetia. Kegiatan diselenggarakan di Minum Kopi, sebuah kafe di daerah Medan Johor yang dikelola oleh alumni FISIP USU, pada pertengahan Agustus 2020. 


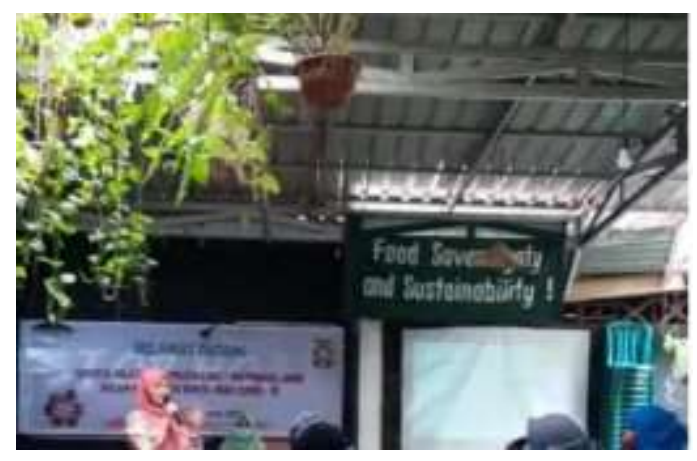

Gambar 2.1. Penyampaian materi

\section{HASIL DAN PEMBAHASAN}

Materi yang disajikan kepada peserta kegiatan antara lain adalah definisi berita, hal apa saja yang menjadi nilai-nilai berita, definisi berita hoaks, serta ciri-ciri berita hoaks.

\subsection{Berita}

Berita adalah laporan yang tepat waktu mengenai fakta atau opini yang memiliki daya tarik atau hal penting bagi masyarakat luas Charnley (dalam Muda, 2005). Tentu tidak semua hal atau peristiwa dapat dijadikan berita, melainkan ada nilai-nilai yang mendukungnya. Nilai-nilai tersebut antara lain:

a. Waktu; harus ada unsur 'cepat dan terkini' dalam pemberitaan. Peristiwa yang baru terjadi dan langsung disiarkan akan menarik perhatian masyarakat. Apalagi dengan kehadiran internet dan media baru saat ini, berbagai peristiwa dapat kita saksikan dalam genggaman tangan dalam hitungan detik saja.

b. Ketokohan; mesti ada unsur figur yang dikenali oleh masyarakat ketika mengangkat suatu berita. Menteri X terlibat korupsi atau pesepak bola legendaris meninggal dunia, misalnya, akan menjadi bahan pemberitaan oleh media.

c. Kedekatan; yang dimaksud kedekatan di sini adalah objek berita memiiki kemelekatan dengan audiensnya. Misalnya, orang Sumatra Utara akan memberikan perhatian lebih terhadap berita mengenai meletusnya Gunung Sinabung, terlebih penduduk yang berada di sekitar lokasi tersebut, ketimbang audiens yang ada di Jakarta. Ini dikarenakan hal tersebut dapat memberikan dampak langsung bagi kehidupan baik sosial maupun ekonomi bagi masyarakat di Sumatra Utara itu sendiri.

d. Keluarbiasaan; ada unsur luar biasa yang akan menjadikan seseorang, benda, atau peristiwa sebagai objek berita. Peristiwa tsunami tahun 2004, salah satu contohnya. Keluarbiasaan peristiwa tersebut tentu akan dikenang oleh orang-orang yang hidup saat peristiwa itu terjadi. Melalui pemberitaan di medialah, seluruh dunia dapat 'menyaksikan' tragedi besar tersebut.

e. Konflik; pertengkaran, peperangan, adalah elemen-elemen yang masih menjadi 'favorit' masyarakat untuk disaksikan melalui media, baik layar kaca maupun media cetak. Bukan hanya peristiwa sesungguhnya, namun konten-konten hiburan seperti film, sinetron, 
maupun konten media sosial masih mengangkat tema ini untuk menarik perhatian pemirsanya.

\subsection{Berita Hoaks}

Beberapa arti dari berita hoaks antara lain; berita bohong, berita tidak bersumber, atau informasi yang memang sengaja disesatkan. Terdapat beberapa penyebab munculnya berita hoaks di media yang kadang-kadang dapat meresahkan masyarakat, yaitu (Wikipedia, 2020);

a. Jurnalisme yang lemah; si wartawan sebagai pembuat berita bisa jadi tidak menerapkan prinsip-prinsip jurnalistik pada saat meliput dan menulis beritanya, misalnya tidak melakukan cek dan ricek dengan tepat. Dikejar target agar berita dapat segera tayang dapat memicu hal ini terjadi.

b. Perkembangan internet; teknologi komunikasi dan informasi yang kian pesat membuat penyampaian berita juga semakin cepat. Pesan-pesan berantai yang beredar di grup-grup media sosial seperti WhatsApp, misalnya, cepat sekali tersebar dikarenakan jaringan internet yang semakin meluas.

c. Faktor ekonomi; banyak pihak yang memang sengaja menciptakan kebohongan dengan tujuan meraup keuntungan, terutama di media digital. Ada kompensasi yang dibayarkan oleh platform penyedia akun berita apabila berita tersebut dibuka oleh khalayak (hit) seperti melalui iklan-iklan.

d. Media abal-abal; banyak media yang saat ini muncul tanpa jelas siapa pendiri dan status perusahaannya. Bisa jadi dibuat dengan tujuan tertentu, mulai dari motif ekonomi, sosial, hingga politik.

e. Pendidikan dan literasi media yang lemah di kalangan masyarakat; jika 4 hal di atas adalah dari sisi media, maka poin ke-5 ini kita lihat dari sisi masyarakat sebagai konsumen atau khalayak media. Kalangan masyarakat kita secara umum belum mendapatkan pendidikan dan pelatihan mengenai program literasi media ini. Semestinya, literasi media sudah dimasukkan dalam kurikulum wajib nasional oleh pemerintah mengingat semakin kuatnya paparan teknologi komunikasi dan informasi.

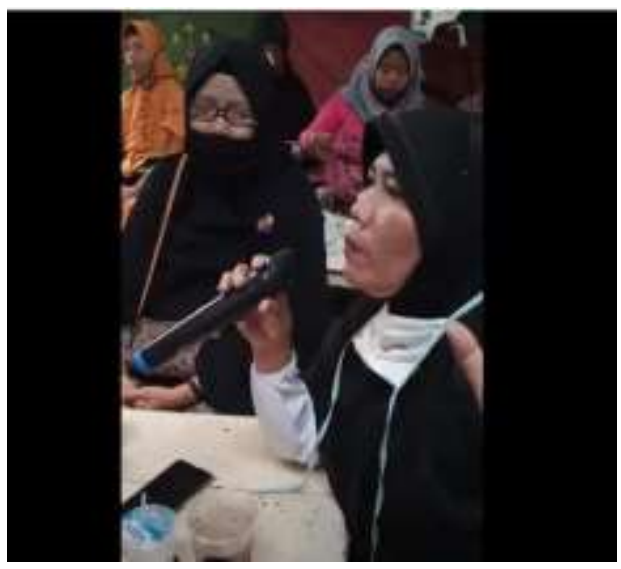

Gambar 3.1. Peserta bertanya dalam sesi taya jawab 
Moulita, et al Media Literacy for Herbalist in Medan City

\subsection{Ciri-ciri dan Contoh Berita Hoaks}

Disarikan dari pernyataan Staf Ahli Menteri Komunikasi dan Informatika Bidang Hukum Henri Subiakto (Kartika, 2019), ciri-ciri pesan hoaks atau berita bohong serta ujaran kebencian yang sering menyebar di media sosial, antara lain:

a. judul yang provokatif; tujuannya adalah agar khalayak terpancing untuk membuka berita tersebut (klik). Padahal isinya sering kali tidak sesuai dengan judulnya,

b. pesannya tidak lengkap; unsur-unsur berita seperti $5 \mathrm{~W}+1 \mathrm{H}$ tidak terpenuhi dalam teks berita semacam ini. Tidak jelas siapa yang menjadi pelaku dalam berita atau kapan dan bagaimana berita tersebut terjadi, dan seterusnya,

c. minta disebarluaskan; untuk menambah kehebohan di masyarakat, si pembuat berita akan menambah embel-embel untuk menyebarkan beritanya tersebut seolah-olah menimbulkan kesan sangat penting dan mendesak untuk dibaca,

d. manipulasi foto dan keterangannya; banyak sekali foto-foto tokoh, artis, ataupun peristiwa yang diedit untuk mendukung berita hoaks yang dibuat. Masyarakat harus jeli melihat dan mengecek kebenarannya. Bisa melalui situs pengecek fakta atau bertanya kepada orang yang lebih paham,

e. sumbernya tidak jelas; tidak dicantumkan dengan jelas siapa si pembuat berita. Ini banyak sekali beredar di media-media sosial. Berita yang dikemas dengan judul yang provokatif serta kata-kata yang bombastis, namun tidak disertakan siapa penulisnya. Pada sisi lain, sering juga beredar berita yang mengatasnamakan tokoh-tokoh tertentu di masyarakat, misalnya profesi dokter dan sebagainya.

Berikut adalah contoh-contoh berita hoaks yang pernah beredar dan menghebohkan masyarakat. Peserta penyuluhan diajak berpikir dan membayangkan seperti apa kerugian yang ditimbulkan terutama bagi para pemilik usaha dengan beredarnya berita-berita semacam ini; beras palsu, telur palsu, pasar mau ditutup, dan lain-lain. Oleh karenanya, sangat penting bagi masyarakat, khususnya peserta kegiatan ini, untuk bersikap tenang dalam merespon pemberitaan yang diterima agar dapat berpikir jernih dan bila perlu melakukan pengecekan fakta melalui situs tertentu di internet.

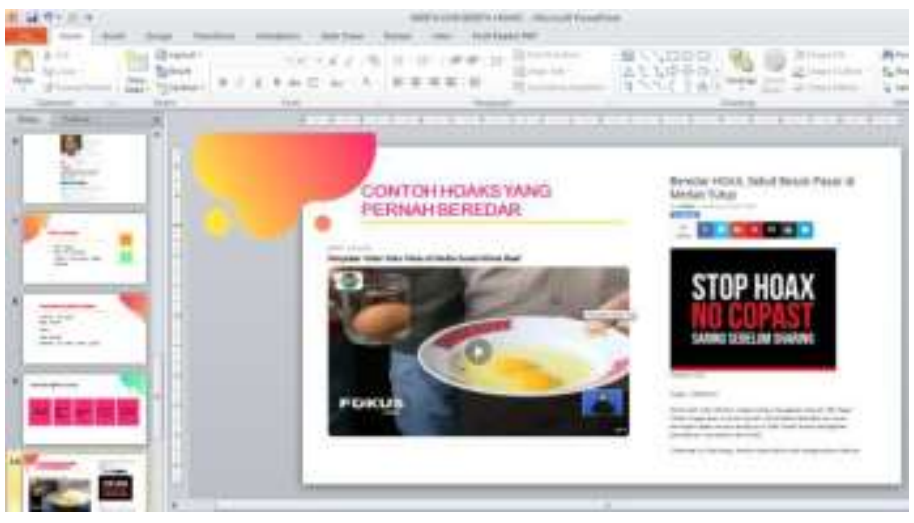

Gambar 3.2. Contoh berita hoaks 


\section{KESIMPULAN DAN SARAN}

Tim pengabdian dan YP2M telah membangun kerja sama yang baik hingga terlaksananya kegiatan pengabdian kepada masyarakat ini. Pihak YP2M juga merespon positif penyuluhan yang diberikan kepada para anggotanya sebab menambah pengetahuan mereka mengenai berita hoaks yang sering muncul di media sosial.

Pelaksanaan program pengabdian di bidang literasi media seperti ini tentunya perlu terus digiatkan untuk mengimbangi semakin lajunya perkembangan teknologi informasi dan komunikasi. Sebab, hal tersebut akan diiringi pula oleh semakin kuatnya paparan dan peredaran berita-berita yang tidak bertanggung jawab terhadap kemaslahatan bersama. Oleh karena itu, setiap komponen dalam masyarakat perlu bekerja sama agar semakin cerdas dan bijak dalam memanfaatkan media dan menyikapi isi dari media tersebut.

\section{UCAPAN TERIMA KASIH}

Tim pengabdian mengucapkan terima kasih kepada LPPM Universitas Sumatera Utara, YP2M, serta semua pihak yang telah mendukung terlaksananya program pengabdian ini.

\section{REFERENSI}

Herlina, Dina. (2019). Literasi Media, Teori dan Fasilitasi. Bandung: Rosda Karya.

Kartika, Mimi. 20 Agustus 2016. Ciri Hoaks Menurut Kemenkominfo. Republika. Diakses dari https://nasional.republika.co.id/berita/pwis1s459/ini-ciri-hoaks-menurut-kemenkominfo

Iriantara, Yosal. (2009). Literasi media: Apa, Mengapa, Bagaimana. Bandung: Simbiosa Rekatama Media.

Muda, Deddy Iskandar. 2005. Jurnalistik Televisi Menjadi Reporter Profesional. Remaja Rosda Karya, Bandung.

Redaksi. 12 Juni 2016. YP2M Berperan Dalam Perekonomian dan Pemberdayaan Perempuan. Kabar Medan. Diakses dari https://kabarmedan.com/yp2m-berperan-dalam- perekonomiandan-pemberdayaan-perempuan/

Tamburaka, Apriadi. (2013). Literasi Media: Cerdas Bermedia Khalayak Media Massa. Jakarta: Raja Grafindo Persada.

Wikipedia. 2020. Berita Bohong. Diakses dari https://id.wikipedia.org/wiki/Berita_bohong 